\title{
The Evangelical Left and the Future of Social Conservatism
}

\author{
David R. Swartz
}

Published online: 29 November 2011

(C) Springer Science+Business Media, LLC 2011

In 1970 Mark Hatfield, a U.S. senator from Oregon, noted critic of the Vietnam conflict, and an evangelical, gave the commencement address at Fuller Theological Seminary in Pasadena, California. Expecting to find seminarians who viewed war in Vietnam as a holy cause against godlessness and communism, Hatfield was shocked by shows of solidarity with his own dovish stance. During the processional, students in the balcony unfurled a banner that read, "We're with you, Mark." Two-thirds of the seminary graduates marching forward to receive their diplomas wore black armbands over their gowns in protest against the war. Hatfield, co-author of the Hatfield-McGovern Amendment to end the Vietnam War, wrote later that for the first time he sensed that "there were countless evangelicals, who because of their faith in Christ, could not condone the immoral and barbarian violence our nation was inflicting throughout Indochina."1

Imagine Hatfield - a liberal Republican, an antiwar evangelical, a pro-life and pro-welfare environmentalistsurviving in today's political climate. In the 1960s and 1970s Hatfield not only survived, but he flourished. He never lost an election after high school and served in the U.S. Senate for over 30 years. It seems surprising now, given the ascendance of the religious right in the 1980s, but there were many evangelicals who, like the senator, were pro-life on abortion, antiwar on Vietnam, internationalist in diplomacy, and pro-government intervention on poverty.

${ }^{1}$ Mark Hatfield, Between a Rock and a Hard Place (Waco, Texas: Word Books, 1976).

D. R. Swartz $(\triangle)$

Department of History, Asbury University,

One Macklem Drive,

Wilmore, KY 40390, USA

e-mail: david.swartz@asbury.edu
Some, like the Christian World Liberation Front of Berkeley and Sojourners of Chicago and Washington, D. C., formed intentional communities. Some, like Ron Sider, author of Rich Christians in an Age of Hunger, questioned the efficacy of capitalism and promoted simple living. Many populated evangelical colleges and state universities. Some, like Hatfield and Harold Hughes, senator from Iowa, ran for political office. Some published magazines such as the Post-American (55,000), Right On (65,000), HIS $(90,000)$ with impressive subscription totals. To many observers, the evangelical left was the face of politicizing evangelicalism ahead of the Moral Majority. In the 1970s, a decade in which evangelicalism and the Republican Party were less synonymous, Hatfield was not the anachronism he would be today.

We would do well to remember Hatfield and his cohort as we consider the increasingly fragmented, amorphous, and fluid nature of contemporary conservatism. The evangelical left reminds us that social conservatism is an unstable construct whose political and moral commitments change over time - and that evangelicals, one of its primary constituencies, are likewise culturally and politically ambivalent. On one hand, younger Americans are more pro-life on abortion, one of the typical measures of social conservatism. On the other hand, younger Americans increasingly support gay marriage and seem to be elevating economics above traditionalist morality. The old categories-social conservative opposition to civil marriage, biological intervention in young and old life, economic regulation, and the privatization of religion - do not seem to hold.

Using historical and global lenses of analysis can illuminate why these countervailing and puzzling trends should not be surprising. The marriage of conservatism and evangelicalism was not inevitable. Nor is it inevitable that current alignments will persist. 


\section{Evangelical Flexibility in a Shifting American Electorate}

The history of the twentieth century shows that political structures are flexible, capable of sudden electoral and ideological shifts. Before the GOP was "God's Own Party," it was conspicuous for its lack of religious rhetoric. To be sure, William F. Buckley, representing the traditionalist wing of the Republican Party, decried the loss of faith from his alma mater Yale and the nation. But in the early and mid-twentieth century, secular business elites dominated the Republican Party, whose oligarchs felt little compulsion to kowtow to the desires of evangelical, Catholic, and Mormon conservatives. Other sources of modern conservatism were manifestly anti-religious. Ayn Rand's libertarianism mocked faith. She disdained religion's focus on generosity, community, and unselfishness. Buckley returned Rand's antipathy, writing a mean-spirited obituary that called Rand "intolerably impolite, impossibly arrogant, obstinately vindictive." ${ }^{2}$ Only a shared admiration for a robust, minimally regulated capitalism - and the mood of the Cold War-kept this very strained marriage of traditional religion and libertarianism together.

American politics to the left of Rand and Buckley has shared this mutability. It is hard to remember now, given the exotica and high drama of the 1968 and 1972 Democratic national conventions, but well into the 1960s, Democrats claimed the moral and religious high ground. The heart of the Democratic Party consisted of anticommunist, cultural conservatives with strong ties to the New Deal, labor, and traditional religion. New Deal programs, argues political scientist Alan Wolfe, "often assumed a two-parent family and a family wage."3 Working-class labor unionists and pro-family Catholics alike imbued liberal redistributive programs with this sense of moral traditionalism.

That ethos faded. Democratic traditionalists lost a late 1960s' incursion led by hippies, draft-dodgers, and sexual libertines. By 1972, political scientists Louis Bolce and Gerald De Maio argue, self-identified agnostics, atheists, and persons who seldom, if ever, attended religious services became the face of the Democratic Party. In fact, a full 21\% of Democratic delegates at the convention could be classified as secular in an American population out of which only $5 \%$ considered themselves secular. To many observers, the Democratic Party had become the home for irreligious, politically untenable, culturally excessive activists. $^{4}$

\footnotetext{
${ }^{2}$ Jennifer Burns, Goddess of the Market: Ayn Rand and the American Right (Oxford: Oxford University Press, 2009), 131.

3 Alan Wolfe, "Whose Body Politic?" The American Prospect (December 1, 1993), 99.

${ }^{4}$ Louis Bolce and Gerald De Maio, "Our Secularist Democratic Party,” Public Interest 149 (Fall 2002), 3-20.
}

As secular activists flooded into the Democratic Party, religious conservatives exited. Regularly attending Catholics, a key constituency in the New Deal coalition, gradually but substantially left the Party. Richard John Neuhaus, a strongly committed Lutheran civil rights activist, veered rightward in the 1970s. In his seminal book, The Naked Public Square (1984), Neuhaus decried the exclusion of religious language from the civic sphere. Likewise, evangelical Richard Lovelace feared that a "secular religion" had "placed a moratorium on God-talk." Democratic leaders, under pressure from secularist and prochoice activists, chose not to speak in moral-religious terms, and the Party hemorrhaged evangelicals and Catholics. If the Republican Party was not always the party of traditionalist conservatism, nor was the Democratic Party the party of secularism. ${ }^{5}$

Even as evangelicals flooded into the Republican Party, they still exhibited remarkable political diversity. The heavily documented mobilization on the right has obscured evangelical racial activists, Vietnam protesters, hippies, and New Leftists. In 1972, some formed Evangelicals for McGovern. In 1973, they produced the provocative Chicago Declaration, which denounced racism, sexism, nationalism, and the Vietnam War. For a time, it seemed that these progressive activists were on the leading edge of a new movement. We know now that they were not. Instead the evangelical left was upstaged by the religious right and its significant mobilization for Ronald Reagan. Yet even during Reagan's administration, a significant minority of between $30 \%$ and $40 \%$ of evangelicals voted Democratic. Into the twenty-first century, a surprisingly strong faction of non-rightist evangelicals - $45 \%$ of all evangelicals called themselves moderates and $19 \%$ liberals in a 2000 Princeton University survey-persisted. ${ }^{6}$ These numbers greatly complicate the popular dichotomy between liberal, mainline, and social gospel Christians on one hand and conservative fundamentalist Christians on the other. To this day, political moderates and leftists - as represented by Sojourners, Evangelicals for Social Action, and the Association for Public Justice - comprise more than a third of American evangelicals and point to the political, theological, and cultural diversity of the movement.

\footnotetext{
${ }^{5}$ Geoffrey Layman, The Great Divide: Religious and Cultural Conflict in American Party Politics (New York: Columbia University Press, 2001), 189-199; Richard John Neuhaus, The Naked Public Square: Religion and Democracy in America (Grand Rapids, Mich.: Eerdmans, 1984); Richard Lovelace, Dynamics of Spiritual Life: An Evangelical Theology of Renewal (Downers Grove, Ill.: InterVarsity Press, 1979), 280.

${ }^{6}$ For the Religion and Politics 2000 survey investigated by Robert Wuthnow of Princeton University, see Corwin E. Smidt, "Evangelical and Mainline Protestants at the Turn of the Millennium: Taking Stock and Looking Forward," paper presented at Southern Methodist University, 2002.
} 
Given evangelicalism's remarkable diversity, the most salient variable in evangelical politics has less to do with the supposed essential traits of evangelicalism and more to do with outside political conditions. The movement is not inherently conservative or universally fixed to individual solutions to social problems. Rather, the socio-economic, racial, and ideological platforms of the political parties have very much determined the extent and direction of evangelical politics. To use a counter-factual argument, evangelicals may have taken a very different trajectory, if in the 1970s there had existed an indifferent Republican Party and a welcoming Democratic Party. Had Democrats, for instance, taken a pro-life stance in the 1970s, or even remained neutral on abortion, more evangelicals might now hold progressive stances on economics and diplomacy. The collapse of the evangelical left in the late 1970s and the rise of the religious right in the early 1980s were anything but inevitable. And if conditions continue to change, as recent polls suggest, it is anything but inevitable that the majority of evangelicals will remain loyalists of the Republican Party. The fluidity of evangelical politics amidst an inherently fragmented movement means that essentialist notions of evangelicalism, often based on the very small sample size of rightist partisan politics in the last several decades, will always need revision.

The nature of evangelicalism itself encourages fluid political configurations. The National Association of Evangelicals proper consists of 43 member denominations, and scholars consider at least a thousand more of the nearly 4,000 Protestant denominations in the United States to be theologically evangelical. Even these astonishingly high numbers don't tell the whole story, given the decreasing salience of denominational markers. Many evangelicals now identify primarily with social service agencies, missionary organizations, colleges, individual congregations, or even evangelical celebrities. Reinforced by the democratizing impulse of the Second Great Awakening in the early nineteenth century and the decentralized "priesthood of all believers" theology that undergirds the modern movement, most sectors of evangelicalism shun hierarchical systems of governance. While this bottom-up structure allows the movement to react to market forces, in turn giving it a stunning resilience and a capacity for growth, it also hinders political coherence. As evangelicals reach out to different social classes, geographies, and ethnicities with their foremost message of personal salvation, they can rarely bring themselves to force converts into a particular political perspective. Lacking a developed tradition of political thought, evangelicalism has historically been characterized by great diversity in both political method and theory.

A long Protestant narrative dating back to the Reformation teaches this historical lesson. The Reformation, particularly the Anabaptist wing (often called the leftwing of the Reformation), challenged the establishment in a frenzy of populist, democratic, and anti-hierarchical fervor. Centuries later British abolitionists challenged the slave trade. In the nineteenth century, some American evangelicals dissented from their Whiggish peers to establish communitarian utopias. Others worked on social issues such as temperance, abolition, industrialization, and suffrage. North Carolinian populists for a time challenged Jim Crow. Radical and moderate forms of both progressivism and conservatism have always existed within a politically ambivalent evangelicalism. That some evangelicals in the 1970s and 1980s would plunge into right-wing politicsand that some would stridently challenge that plunge-has precedent at many points in American and global history. ${ }^{7}$

\section{Failure of the "Consistent Life" Ethic}

The fate of the promising 1970s evangelical left illuminates this theoretical point about evangelical flexibility in a shifting American electorate. In the 1980s the evangelical left fashioned its idiosyncratic political planks into a "consistent life ethic," which they borrowed from American Catholics. They linked opposition to U.S. imperialism in Central America to a much larger agenda that also opposed patriarchy, nuclear proliferation, poverty, and abortion.

Staking its identity and future on this overarching concern for "life," the progressive evangelicals sought to straddle left and right. "The energy of the pro-life movement must be removed from the ideological agenda of the New Right," warned Sojourners' Jim Wallis in late 1980 as passion grew in conservative evangelical circles against abortion. Instead, Wallis continued, the evangelical left should rally around the pro-life cause as a "threshold issue" that might soften evangelical conservatives and moderates into accepting other progressive causes. Ron Sider, founder of Evangelicals for Social Action, argued that such a strategy was feasible. He pointed out in a 1981 memo to top evangelical leaders that a recent Gallup Poll showed that $20 \%$ of evangelicals were "left of center," $37 \%$ were "right of center," and $30 \%$ were centrist. If more than half of evangelicals were "non-right," Sider asked, then why was the Moral Majority constructing the terms of evangelical politics? Not only was the Christian right's agenda "not biblical enough," it failed to represent

\footnotetext{
${ }^{7}$ On Anabaptism, see George Williams, The Radical Reformation (Philadelphia: Westminster Press, 1962). On William Wilberforce and British Abolitionism, see Adam Hochschild, Bury the Chains: The British Struggle to Abolish Slavery, London: Macmillan, 2005). On North Carolina populists, see Joe Creech, Righteous Indignation: Religion and the Populist Revolution (Urbana: University of Illinois Press, 2006).
} 
evangelicalism as a whole. A political vacuum existed, wrote Sider, among evangelicals who hold to the Moral Majority's "basic pro-life and pro-family concerns" but do not resonate with its positions on the nuclear arms race, poverty, wealth, and race. ${ }^{8}$

Activism within the evangelical left soon began to reflect the new rhetoric. At a Sojourners-organized "Peace Pentecost" demonstration in May 1985, participants touched on all points of the consistent pro-life ethic. Featured speaker Ron Sider, who was just completing his book Completely Pro-Life with InterVarsity Press, rallied participants outside the White House. Carrying signs that read "Choose Life: All Life is Sacred," protesters prayed against "the twisted priorities of a nation that reverses the biblical wisdom by busily beating plowshares into swords." Next they proceeded to the State Department to denounce an American "promotion of violence and terror" in Central America; then to the Soviet embassy, where they prayed for the people of Afghanistan, who have "been brutally invaded by another arrogant superpower"; then to the South African embassy to pray against apartheid; then to the Supreme Court, where they interceded for the victims of crime and for those on Death Row; and finally to the Department of Health and Human Services where they "prayed for the unborn and for an agenda of justice and compassion for women and children that will create alternatives to the desperate, painful choice of abortion." The cumulative protests yielded 248 arrests and generated impressive media attention. ${ }^{9}$

The new emphasis culminated in the formation of JustLife. This organization issued voter guides, contributed to 22 "life-friendly" Senate and House candidates in 1986, conducted petition drives, and publicized its endorsements of candidates in local newspapers across the nation. JustLife also introduced eight pro-life legislative bills with provisions for informed consent, family consent, viability testing for women 20-months pregnant, no public support for abortions, coordination of services for pregnant women, parental leave from work, Medicaid for unborn children, and adoption subsidies. In 1988 the organization issued a glossy voter guide. In it, Billy Graham, Ron Sider, and Joseph Cardinal Bernardin, urged "aggressive negotiations" with the Soviet Union to end the nuclear arms race, governmental programs that "empower the poor to become

\footnotetext{
${ }^{8}$ Wallis, "Coming Together on the Sanctity of Life," Sojourners 9, No. 11 (November 1980), 3-4; Ron Sider, "What Should Be the Shape of the Evangelical Political Involvement in the 80's?" March 20, 1981, Folder "1981," ESA Archives.

${ }^{9}$ On Peace Pentecost, see "Police Arrest Christians in Capital Protest," Los Angeles Times, May 28, 1985, p. 2; Jim Wallis, "Dissenting from the Right," Newsweek (September 17, 1984), 32; Wallis, "The Court Prophets," Sojourners 13, No. 8 (September 1984), 3-4.
}

self-sufficient," and an end to abortion, except when necessary to save the life of the mother. ${ }^{10}$

Evidence soon mounted, however, that the grand evangelical coalition would not materialize. By 1989 JustLife had not exceeded 6,000 members. Despite endorsing 56 candidates in 1990, JustLife contributed only $\$ 22,000$ to their political campaigns. In 1993, after mustering only $\$ 6,000$ in donations to candidates, the PAC folded, deeply in debt after an unsuccessful emergency fundraising campaign. ${ }^{11}$

The evangelical left's "consistent life" thrust failed because of the cultural and political realities of the 1980s. Both JustLife and the broader movement simply did not fit the hardening American political party structure. During the 1980s Stephen Monsma, a pro-life evangelical Democrat from Michigan, lost two political bids: one for the U.S. House of Representatives in 1984 and one for the Michigan Senate in 1985. In both cases, hostility from Democratic colleagues toward his pro-life stance on abortion (despite his reliable support of welfare measures and a tight race for party superiority in the State Senate) plagued Monsma's campaign. The New York Times reported that Monsma's opposition to state financing of abortions caused Democratic funds "to dry up" in election campaigns. On the other side, Monsma had previously secured the endorsement of Michigan's Right to Life organization, but many insiders loudly objected because it was in the interest of their cause to retain Republican control of the Senate. Monsma gave up and moved to California. Robert Casey of Pennsylvania, Tony Hall of Ohio, Don Bonker of Washington, Bill Nelson of Florida, and Bob Casey of Pennsylvania soldiered on, but these pro-life Democrats, like Monsma, were also targets of both Democratic and Republican activists. ${ }^{12}$

By failing to conform to political orthodoxy, the evangelical left forfeited its chances for large-scale mobi-

\footnotetext{
${ }^{10}$ On the formation of JustLife, see Ron Sider, "Building for the Future," ESA Update 9, No. 3 (September 1987), 1-2; Jones, "Radical Evangelical Political Theology," 385; Jack Smalligan, "What Are PACs and How JustLife Fits In," ESA Update 9, No. 4 (NovemberDecember 1987), 1, 3.

${ }^{11}$ Kathleen Hayes and Ron Sider, eds., JustLife/88: A 1988 Election Study Guide for Justice, Life, and Peace (Philadelphia: JustLife Education Fund and Eerdmans, 1988); Kathleen Hayes, ed., JustLife/ 90: 1990 Study Guide for Justice, Life, and Peace (Philadelphia: JustLife Education Fund, 1990); Mary E. Bendyna, "JustLife Action," 198, 200, 290, in Risky Business? PAC Decisionmaking in Congressional Elections, eds. Robert Biersack, Paul S. Herrnson, and Clyde Wilcox (Armonk, N.Y.: M.E. Sharpe, 1994), 195-201.

${ }^{12}$ On secular leftist opposition, see Bill Weld-Wallis, "Abortion: The Political Dilemma," Sojourners 13, No. 9 (October 1984), 4-5. On Monsma, see Adam Clymer, "Democrats Shaping Election as Referendum on Economy," New York Times, October 3, 1982, p. 1, 30; "G.O.P. Retains Edge in Michigan Senate," New York Times, March 28, 1985, p. A19; Medema quoted in Peter Steinfels, "Beliefs: The Plight of Voters Whose Views on Abortion Are at Odds With Their Party's," New York Times, March 28, 1992, p. 10.
} 
lization. By contrast, the religious right had successfully attached itself to a burgeoning conservative movement and the Republican Party. Groups like the Moral Majority quickly outpaced progressive evangelical alternatives. By 1990 the evangelical left had been left behind.

\section{Future Prospects}

While progressive evangelicals still suffer from homelessness, their precarious position may not be permanent. Twenty years later, we may now be entering a new era in which evangelicals could be siphoned away from old forms of social conservatism toward a reenergized evangelical left. One key indication is that Democratic activists have begun to encourage younger moderate and progressive evangelicals. Senator Chris Dodd, a Catholic from Connecticut, said in 2007 that his party had made "a huge mistake over the years" by not talking about how faith informs public policy. The most prominent contenders for the 2008 presidential nomination sought to avoid repeating that strategic misstep. Hillary Clinton signed up Burns Strider, a born-again evangelical from Mississippi and leader of the Democratic Faith Working Group, as senior advisor and director of faith-based outreach. Barack Obama hired Joshua DuBois, a young minister with the Assemblies of God, as a religious affairs advisor. In 2008 Obama gave an interview to Christianity Today and publicly identified several evangelicals, including Jim Wallis, Joel Hunter, T. D. Jakes, and Kirbyjon Caldwell, as his spiritual advisors. As the campaign heated up, Democratic candidates visited numerous evangelical venues sponsored by Sojourners, Rick Warren's Saddleback Church, and Messiah College. Organizations such as Democrats for Life and Faithful Democrats also gained steam. Common Good Strategies, a political action committee established by Mara Vanderslice and Eric Sapp, promoted seven Democratic candidates, all of whom won their 2008 elections. Not since William Jennings Bryan have Democrats made such overtures to evangelicals. ${ }^{13}$

Many evangelicals themselves seem to be ripe for the picking. While the evangelical left may have failed electorally in the 1980 s, it has continued to point many evangelicals in a progressive direction on issues of gender, poverty, and the environment. The 2005 "Evangelical Call to Action," for example, decried human-caused climate change and called for immediate policy solutions. Megachurch pastor Rick Warren, an early supporter of President George W. Bush who joined monthly conference calls with the White House in the early 2000s, has distanced himself

\footnotetext{
${ }^{13}$ Laurie Goodstein, "Without a Pastor of His Own, Obama Turns to Five," New York Times, March 14, 2009.
}

from the Republican establishment. Anointed by many as Billy Graham's successor, Warren has more recently added social issues to his agenda of saving souls. During a 2003 trip to South Africa, he visited a small church that worshipped in a tattered tent that housed 25 children orphaned by AIDS. "I realized they were doing more for the poor than my entire mega-church," Warren said. "It was like a knife in the heart." He mobilized his 7,500-member Saddleback Church in Orange County, Cal., using donations from his parishioners and the proceeds of his bestselling spiritual guidebook The Purpose-Driven Life (2002) to fund initiatives on poverty and disease. In 2008, he invited a wide range of presidential candidates, including Barack Obama, Hillary Clinton, and John McCain, to Saddleback for a forum. On January 20, 2009, he delivered the invocation at Obama's inauguration. Warren's broadening trajectory mirrors that of many young evangelicals. Among this important subset, George Bush's approval rating dropped from $87 \%$ in 2002 to $45 \%$ by the end of his presidency, a plunge reminiscent of Jimmy Carter's sagging popularity among evangelicals in the late 1970s. All this represents an evangelical trend toward a more flexible and centrist politics. Sociologist Michael Lindsay notes that "fully $70 \%$ of evangelicals in America do not identify with the religious right."

This trajectory could accelerate if the Republican Party opts for an economic emphasis over social issues. Many Tea Partiers, according to a recent study by The Pew Forum on Religion and Public Life, are part of the religious right. But while there is overlap, the resonance should not be exaggerated. A full 55\% are not evangelical, and the Tea Party's official platform is striking in its disinterest in social conservatism. While willing to append a spiritual component to its agenda, the Tea Party in its official statements clearly privileges lower taxes and local initiative over opposition to abortion. Moderate (and even some conservative) evangelicals have reacted to the new emphasis. "There's a libertarian streak in the tea party movement that concerns me as a cultural conservative," said Bryan Fischer, director of Issue Analysis for Government and Public Policy at the American Family Association. The Public Religion Research Institute (PRRI) findings of late 2010, according to E.J. Dionne, reflect "real tensions between what might be called compassionate conservatism from the Bush-era and a newer, harder-edged Tea Party." White evangelicals were significantly less likely than Tea Partiers to say that repealing the health care reform law should be

\footnotetext{
${ }^{14}$ On Warren's social transformation, see Nicholas Kristof, "Evangelicals a Liberal Can Love," New York Times, February 3, 2008. On the evangelical non-right, see Michael Lindsay, "Evangelicals and the Public Square," a panel discussion hosted by the Pew Forum on Religion and Public Life, Thursday, October 11, 2007, Washington, D.C.
} 
the most important priority for the GOP, that discrimination against women is no longer a problem, that blacks have received too much government attention, or that it's a big problem if some Americans have more chances in life than others. ${ }^{15}$ The stridency and incivility of some libertarian Tea Partiers, according to some critics, may very well alienate people of "The Book," which has much more to say about poverty than about the virtues of limited government and low taxes. Evangelicals may help fray the connective tissue of the conservative movement, whose constituent parts of libertarianism and cultural traditionalism are no longer held together by an anti-communist animus against a godless Soviet Union.

A recent Pew Research Center poll on evangelical political affiliation affirms the anecdotal evidence for these trajectories. Since 2005, young white evangelicals' identification with the Republican Party dropped by $15 \%$ points. Will these developments lead to a strong identification of evangelicals with the Democratic Party? So far, it has not been strong. Young white evangelicals' identification with the Democratic Party rose only $5 \%$. Stronger ties, should they form, will likely take time. After all, many evangelicals are tied to Republicanism through identity politics. The most important variable will be the Democratic Party's handling of pro-life evangelicals. A 2007 survey of evangelical politicians by Michael Lindsay found that the top reason given for their political affiliation was their party's pro-life position. If Democrats open up to pro-life policies, unexpected new political alignments could take place. ${ }^{16}$

The most intriguing Pew finding identified a growing evangelical trend away from partisan identification altogether. Among young white evangelicals there has been a $10 \%$ jump for independence since 2005. Social scientists have begun to assign new terminology to these new evangelicals. Political scientist John Green calls them "freestyle evangelicals." Michael Lindsay calls them "cosmopolitan evangelicals." 17 Among these independent evangelicals include Rick Warren, who seeks to tackle global hunger and the AIDS epidemic by sidestepping electoral politics and seeking a third way involving direct action and

\footnotetext{
${ }^{15}$ E.J. Dionne and William A. Galston, "The Old and New Politics of Faith: Religion and the 2010 Election," The Brookings Institution, November 17, 2010.

${ }^{16}$ On party identification, see Dan Cox, "Young White Evangelicals: Less Republican, Still Conservative," The Pew Forum, September 28, 2007; Lindsay, Faith in the Halls of Power, 41.

${ }^{17}$ For "freestyle evangelicals," see John Green and Steven Waldman, "Freestyle Evangelicals: The Surprise Swing Vote," Beliefnet, September 22, 2003. For "cosmopolitan evangelicals," see Lindsay, Faith in the Halls of Power, 28. On the role of evangelicalism in the fraying of conservatism, see Darryl G. Hart, The Intercollegiate Studies Institute, Last Dance? The Future of the Religious Right and American Conservatism, Speech to The Philadelphia Society, April 28, 2007.
}

non-profits. Bill Hybels, pastor of the megachurch Willow Creek outside of Chicago, told the New York Times that he considered politics a path to "heartache and disappointment." He envisioned a less political, but no-less-socially engaged path that, according to the Times, "would warm a liberal's heart." Warren and Hybels were two of hundreds of prominent evangelicals leaders to sign a document entitled For the Health of the Nation: An Evangelical Call to Civic Responsibility. The politics of this document, like that of the new freestyle evangelicals, spanned the political spectrum, calling for religious freedom, strong families and the protection of children, sanctity of life, care for the poor and vulnerable, human rights, peacemaking, and care for creation. ${ }^{18}$

Given the set of issues articulated by key evangelical leaders such as Hybels and Warren, perhaps a "completely pro-life" reprise of the 1980s is underway. This could make sense of rapidly evolving social conservative categories. It could fit a common-sense interpretation of the New Testament. It could sidestep the gay issue, which is bound to be a losing issue for conservatives. In this new political moment, it could conceivably work better for the new freestyle evangelicals than for the old evangelical left.

Aiding free-style evangelicals moving toward nonpartisan moderation could be groups typically not included in polling numbers on evangelicals. The Pew Forum's racially narrow description of evangelical- "white"excludes millions of black and Hispanic evangelicals with similar notions of theology and piety but different politics. Closer cooperation between white and non-white evangelicals could lead to different political alignments. Second, global evangelicals less constrained by American structures could transform the demographic makeup of American evangelicalism. Third-world Christianity is not just a conservative export of American missions societies. Recent studies of evangelicals in Asia, Africa, and Latin America show the global record on politics to be unpredictable and strikingly variable. Third-world evangelicalism can look conservative on sexual matters, progressive on economics, internationalist in diplomacy, and can span the spectrum on gender issues. In a world where $60 \%$ of the world's Christians now live outside the North Atlantic regionand in a nation increasingly shaped by globalism due to the 1965 Immigration Act-these idiosyncratic perspectives will only continue to carry more weight. ${ }^{19}$

\footnotetext{
${ }^{18}$ For the Health of the Nation: An Evangelical Call to Civic Responsibility (Washington, D.C.: National Association of Evangelicals, 2004). On Hybels, see David Kirkpatrick, "The Evangelical Crackup," New York Times, October 28, 2007.

${ }^{19}$ Philip Jenkins, The Next Christendom: The Coming of Global Christianity (Oxford: Oxford University Press, 2002); Paul Freston, ed., Evangelical Christianity and Democracy in Latin America (Oxford: Oxford University Press, 2008), 28.
} 
To be sure, evangelical conservatism in its current form is fairly entrenched and consists of some of evangelicalism's louder voices. But the analysis should not end there. A global and historical look at theologically conservative Christianity reveals stunning cultural and political diversity. It could very well be that an evangelical left re-emerges with some vitality. It could be that evangelicals retreat to a more apolitical posture. More likely in the short term, as recent polls suggest, evangelicals will freestyle their politics. Even more certain is that both American politics and evangelicalism both have the capacity for new alignments. A 2007 Harris Poll shows that the youngest voter group-Americans aged 18 to 30 - are the least likely to support "the death penalty," "embryonic stem-cell research," "the separation of church and state," "abortion rights," "physician-assisted suicide," or "affirmative action." These same voters are the most likely to support "gay rights" and "same-sex marriage." This combination of views does seem bewildering. But there is no historical reason why social conservatism and evangelical politics must retain the shape of the $1980 \mathrm{~s}$ and 1990s. Fifty years from now, the curious trends we're now observing may have won the day. In the end, historians may judge the religious right, in its tight coupling of moral, social, and economic conservatism, to be the historical outlier.

David R. Swartz is an assistant professor of history at Asbury University. He is author of Left Behind: Progressive Evangelicals in an Age of Conservatism (University of Pennyslvania, 2012). This article is based on a paper given as part of a workshop on the future of social conservatism, directed by Jon Shields and sponsored and funded by the Henry Salvatori Center for the Study of Individual Freedom in the Modern World at Claremont McKenna College, May 20-21, 2011. 